\title{
Safety Model for the Introduction of Robotic Surgery in Gynecology
}

\section{Modelo de segurança para a introdução da cirurgia robótica em ginecologia}

\author{
Mariano Tamura Vieira Gomes ${ }^{1}$ Beatriz Taliberti da Costa Porto ${ }^{1}$ Jose Pedro Parise Filho ${ }^{1}$ \\ Ana Luiz Vasconcelos ${ }^{1}$ Bruna Fernanda Bottura ${ }^{1}$ Renato Moretti Marques ${ }^{1}$ \\ ${ }^{1}$ Hospital Israelita Albert Einstein, São Paulo, SP, Brazil \\ Address for correspondence Mariano Tamura Vieira Gomes, Hospital \\ Israelita Albert Einstein, Av. Albert Einstein, 627, 05652-900, Bloco \\ A1, $5^{\circ}$ andar, sala 508, Morumbi. São Paulo, SP, Brazil \\ Rev Bras Ginecol Obstet 2018;40:397-402. \\ (e-mail: biacostaporto@yahoo.com.br; marianotamura@hotmail.com).
}

\begin{abstract}
Keywords

- robotics

- robotic surgical procedures/adverse effects

- gynecologic surgical procedures/methods

- endometriosis/ surgery

- gynecology
\end{abstract}

Objective To analyze the perioperative results and safety of performing gynecological surgeries using robot-assisted laparoscopy during implementation of the technique in a community hospital over a 6-year period.

Methods This was a retrospective observational study in which the medical records of 274 patients who underwent robotic surgery from September 2008 to December 2014 were analyzed. We evaluated age, body mass index (BMI), diagnosis, procedures performed, American Society of Anesthesiologists (ASA) classification, the presence of a proctor (experienced surgeon with at least 20 robotic cases), operative time, transfusion rate, perioperative complications, conversion rate, length of stay, referral to the intensive care unit (ICU), and mortality. We compared transfusion rate, perioperative complications and conversion rate between procedures performed by experienced and beginner robotic surgeons assisted by an experienced proctor.

Results During the observed period, 3 experienced robotic surgeons performed 187 surgeries, while 87 surgeries were performed by 20 less experienced teams, always with the assistance of a proctor. The median patient age was 38 years, and the median BMI was $23.3 \mathrm{~kg} / \mathrm{m}^{2}$. The most frequent diagnosis was endometriosis (57\%) and the great majority of the patients were classified as ASA I or ASA II (99.6\%). The median operative time was 225 minutes, and the median length of stay was 2 days. We observed a $5.8 \%$ transfusion rate, $0.8 \%$ rate of perioperative complications, $1.1 \%$ conversion rate to laparoscopy or laparotomy, no patients referred to ICU, and no deaths. There were no differences in transfusion, complications and conversion rates between experienced robotic surgeons and beginner robotic surgeons assisted by an experienced proctor.

Conclusion In our casuistic, robot-assisted laparoscopy demonstrated to be a safe technique for gynecological surgeries, and the presence of an experienced proctor was considered a highlight in the safety model adopted for the introduction of the robotic gynecological surgery in a high-volume hospital and, mainly, for its extension among several surgical teams, assuring patient safety. received

October 30, 2017

accepted

April 9, 2018

published online

May 18, 2018
DOI https://doi.org/

10.1055/s-0038-1655746. ISSN 0100-7203.
Copyright $(2018$ by Thieme Revinter

Publicações Ltda, Rio de Janeiro, Brazil
License terms

(c) (i) $\ominus$ (\$) 


\section{Resumo}

Palavras-chave
- robótica
- procedimentos
cirúrgicos robóticos/
efeitos adversos
- procedimentos
cirúrgicos em
ginecologia/métodos
- endometriose/
cirurgia
- ginecologia

Objetivo Analisar os resultados perioperatórios e a segurança da realização de cirurgias ginecológicas por laparoscopia robô-assistida durante a implementação da técnica num hospital comunitário ao longo de 6 anos.

Métodos Este foi um estudo retrospectivo observacional, com análise dos prontuários de 274 pacientes que se submeteram à cirurgia robótica de setembro de 2008 a dezembro de 2014. Avaliamos idade, índice de massa corpórea (IMC), diagnóstico, procedimentos realizados, classificação da Sociedade Americana de Anestesiologia (ASA), presença de um preceptor (cirurgião experiente, com pelo menos 20 casos robóticos), tempo cirúrgico, taxa de transfusão, complicações perioperatórias, taxa de conversão, tempo de internação, encaminhamento para Unidade de Terapia Intensiva (UTI) e mortalidade. Comparamos taxa de transfusão, complicações perioperatórias e taxa de conversão entre procedimentos realizados por cirurgiões experientes com a técnica e cirurgiões iniciantes na robótica, sempre assistidos por um preceptor experiente.

Resultados Durante o período observado, 3 cirurgiões experientes realizaram 187 cirurgias, enquanto que 87 cirurgias foram realizadas por 20 equipes menos experientes, sempre com a presença de um preceptor. A mediana da idade foi 38 anos, e a mediana do IMC foi $23,3 \mathrm{~kg} / \mathrm{m}^{2}$. O diagnóstico mais frequente foi endometriose (57\%) e a grande maioria das pacientes foi classificada como ASA I ou ASA II (99,6\%). O tempo de cirurgia teve uma mediana de 225 minutos, e o tempo de permanência hospitalar teve uma mediana de 2 dias. Observamos $5,8 \%$ de taxa de transfusão, $0,8 \%$ de taxa de complicações perioperatórias, $1,1 \%$ de taxa de conversão para laparoscopia ou laparotomia e não houve pacientes encaminhadas à UTI, nem óbitos. Não houve diferença nos índices de transfusão, complicações e conversão entre cirurgiões experientes e cirurgiões iniciantes na robótica, assistidos por um preceptor experiente. Conclusão Em nossa casuística, a laparoscopia robô-assistida demonstrou ser uma técnica segura para cirurgias ginecológicas, e a presença de um preceptor experiente foi considerada um ponto de destaque no modelo de segurança adotado para a introdução da cirurgia robótica em ginecologia num hospital de grande volume e, principalmente, na sua expansão entre diversas equipes cirúrgicas, mantendo a segurança das pacientes.

\section{Introduction}

In the 1990s, laparoscopy, previously relegated to diagnostic procedures, gained prominence in surgeries on the female reproductive system. ${ }^{1}$ The evolution from open surgery to laparoscopy brought benefits for patients, and robotics represents a technological advancement in minimally invasive surgery. ${ }^{1}$ The word robot refers to compulsory or mandatory work, and the term was created and first used by Karel Capek in 1920, in his play Rossum Universal Robots. The Robotics Institute of America defines a robot as a machine that has a human form of performing tasks, possibly with more precise skills. ${ }^{2}$

Robotic surgery models emerged in the 1980s at the request of the United States Army, which sought alternatives for the surgical treatment of soldiers wounded on the battlefield. ${ }^{3}$ Robotic systems were continually created until the development of the da Vinci System (Intuitive Surgical, Sunnyvale, California, USA), which is now widely used for procedures in different specialties, including gynecology. ${ }^{4}$ In
Brazil, the Hospital Israelita Albert Einstein (HIAE) has pioneered the practice of robot-assisted laparoscopy in several specialties, including gynecology, and has performed a growing number of procedures since 2008 .

Studies have compared the perioperative results of conventional, laparoscopic, and robotic surgeries in the field of gynecology, including benign and malignant surgeries, mainly hysterectomies. ${ }^{5,6}$ The disadvantages of conventional surgery over laparoscopy are clear in terms of abdominal incisions, length of stay, greater need for postoperative analgesia, and higher complication rates. ${ }^{5-7}$ On the other hand, when robotassisted laparoscopy is compared with conventional laparoscopy, it would be expected that complex procedures become safer and more reproducible, as certain difficulties would be overcome. These include limitations on instruments range of motion, two-dimensional vision, tremor, ability to perform laparoscopic sutures, the need for an assistant to hold the camera, and a steep learning curve in the laparoscopy. 4,7

Robot-assisted laparoscopy can be used in many gynecological procedures, including myomectomies, hysterectomies, 
adnexal surgeries, treatment of endometriosis, sacrocolpopexies, tubal reanastomosis, and oncological surgeries, including pelvic and para-aortic lymphadenectomies. ${ }^{8-13}$ However, technological implementation in a surgical environment, especially when it involves several or many teams, with different levels of training and skills, is a great challenge and responsibility because patient safety can never be put at risk, otherwise the use of those tools should be strongly discouraged. Proctors in our hospital are designated by a multidisciplinary surgical committee. They need to be experienced in laparoscopy and recognized as proficient in robotics, with a minimum of 20 robotics cases (usually more than that). Those proctors have the function of supporting other less experienced teams throughout the surgery and handling the robot, with the role of intervening and even performing some steps of the procedure, if necessary. At the end, they evaluate the surgeons' skills in the different tasks of operations. It is also the proctor who formally enables other surgeons to perform procedures on their own after proven proficiency, thus ensuring good surgical results while always prioritizing patient safety.

The objective of this study was to analyze the perioperative results and safety of performing gynecological surgeries using robot-assisted laparoscopy during implementation of the technique over a 6-year period, considering procedures performed with and without a proctor.

\section{Methods}

This retrospective, observational and cross-sectional study was approved by the Institutional Medical Ethics Committee, CAAE: 38045414.7.0000.0071. We analyzed the medical records of 274 patients who underwent gynecological surgeries for benign or malignant diseases at the Hospital Israelita Albert Einstein (HIAE), São Paulo, Brazil, from September 2008 to December 2014. Patients with surgical indication for the treatment of gynecological diseases were included, and patients with non-gynecological procedures were excluded, even if there was a gynecological procedure for them as well.

The study considered each patient age, BMI, ASA classification, and diagnosis. We evaluated the procedures performed, operative time, length of stay, perioperative complications, blood transfusion, conversions (laparoscopy or laparotomy), transfer to the intensive care unit, and mortality. The data were descriptively analyzed using absolute frequency and percentages for qualitative variables and averages, standard deviations, or medians and quartiles for quantitative variables. The median was selected in cases of asymmetric sample distribution. The analyses were performed using SPSS statistical program, version 17.0 (SPSS Inc., Chicago, USA) to compare complications, transfusion rate and surgical conversion between experienced robotic surgeons without proctor and beginner robotic surgeons with proctor assistance.

\section{Results}

The number of surgeries was found to have increased over the course of the study period, with $16(5.8 \%)$ surgeries in
2009, $22(8.0 \%)$ in 2010, $45(16.4 \%)$ in 2011, 38 (13.9\%) in 2012,63 (23\%) in 2013, and 87 (31.8\%) in 2014. In 2008, three (1.1\%) surgeries were performed from September to December. Three teams performed the procedures in 187 patients (68.2\%), with a mean of 62.33 cases per surgeon (range: $27-$ 126). Twenty teams still in their initial robotics learning curve were responsible for 87 cases (31.8\%), with a mean of 4.35 cases per surgeon (range: 1-14), always with the participation of a proctor.

The patients were aged 20 to 84 years, with a median age of 38 years, and the BMI range was 16 to $46.7 \mathrm{~kg} / \mathrm{m}^{2}$, with a median of $23.3 \mathrm{~kg} / \mathrm{m}^{2}$. In the surgical risk evaluation, only one patient had a preoperative ASA score of III $(0.4 \%)$. The others were classified as ASA I or ASA II, indicating low clinical-surgical risk. The following preoperative diagnoses were found: endometriosis, uterine myoma, endometrial cancer, adenomyosis, and benign ovarian tumor. The following procedures were performed: ovarian cystectomy, treatment of intestinal endometriosis, hysterectomy, treatment of deep endometriosis (other than intestinal), myomectomy, oophorectomy, lymphadenectomy and sacrocolpopexy. The most frequent diagnosis was endometriosis, which occurred in 192 patients $(70.1 \%)$. The most frequent procedures were ovarian cystectomy (22\%) and treatment of intestinal endometriosis (20\%) (-Tables $\mathbf{1}$ and $\mathbf{2}$ ).

The diagnoses were included in the study as individual occurrences, given that each patient might have more than one diagnosis at the time of surgical decision. The same was considered for the procedures performed, as different procedures could be necessary during a single patient surgery. The operative time was 55 to 600 minutes, with a median

Table 1 Distribution of surgeries by the preoperative diagnosis $(n=338)$

\begin{tabular}{|l|l|}
\hline Diagnosis & $\mathbf{n}(\%)$ \\
\hline Endometriosis & $193(57)$ \\
\hline Uterine myoma & $120(35.5)$ \\
\hline Endometrial cancer & $10(3)$ \\
\hline Adenomyosis & $10(3)$ \\
\hline Benign ovarian tumor & $5(1.5)$ \\
\hline
\end{tabular}

Table 2 Distribution of procedures performed $(n=501)$

\begin{tabular}{|l|l|}
\hline Procedures & $\mathbf{n}(\%)$ \\
\hline Ovarian cystectomy & $110(22)$ \\
\hline Treatment of intestinal endometriosis & $101(20)$ \\
\hline Hysterectomy & $89(17.8)$ \\
\hline $\begin{array}{l}\text { Treatment of deep endometriosis } \\
\text { (other than intestinal) }\end{array}$ & $85(17)$ \\
\hline Myomectomy & $66(13.2)$ \\
\hline Oophorectomy & $40(8)$ \\
\hline Lymphadenectomy & $9(1.8)$ \\
\hline Sacrocolpopexy & $1(0.2)$ \\
\hline
\end{tabular}


time of 225 minutes (interquartile range [IQR]: 150-280 minute). The postoperative length of stay was 0.5 to 12 days, with a median time of 2 days (IQR: 2-3 days). Transfusions were required in $5.8 \%$ of the surgeries (1-3 red blood cell concentrates). There were complications in $2.6 \%$ of the surgeries and conversion to laparotomy or laparoscopy in $1.1 \%$ of the cases. There were no transfers to the ICU and no deaths (- Table 3 ). There were no differences in complication rates between the group of surgeons with less experience in robotics (who were always assisted by a proctor) and the group of more experienced surgeons (-Table 4).

\section{Discussion}

A 2010 review showed that robotic surgery has gradually become a frequent choice, and this modality has demonstrated good results in terms of reducing trauma and shortening the length of stay, with fewer complications, as

Table 3 Distribution of surgeries by parameters analyzed in the case series $(n=274)$

\begin{tabular}{|l|l|}
\hline Distribution of surgeries & \\
\hline Operative time & Minutes \\
\hline Median (IQR) & $225(150-280)$ \\
\hline Minimum-Maximum & $55-600$ \\
\hline Postoperative length of stay & Days \\
\hline Median (IQR) & $2(2-3)$ \\
\hline Minimum-Maximum & $0.5-12$ \\
\hline Need for transfusion & $\mathrm{n}(\%)$ \\
\hline No & $258(94.2)$ \\
\hline Yes & $16(5.8)$ \\
\hline Amount transfused & $\mathrm{n}(\%)$ \\
\hline None & $258(94.2)$ \\
\hline 1 & $7(2.6)$ \\
\hline 2 & $7(2.6)$ \\
\hline 3 & $2(0.7)$ \\
\hline $\begin{array}{l}\text { Description of perioperative } \\
\text { complications }\end{array}$ & $\mathrm{n}(\%)$ \\
\hline No complications & $272(99.2)$ \\
\hline $\begin{array}{l}\text { Ureteral reconstruction due to } \\
\text { ureteral injury }\end{array}$ & $1(0.4)$ \\
\hline $\begin{array}{l}\text { Colonic fistula, with colostomy } \\
\text { performed }\end{array}$ & $1(0.4)$ \\
\hline $\begin{array}{l}\text { Surgical conversion } \\
\text { (laparoscopy/laparotomy) }\end{array}$ & $\mathrm{n}(\%)$ \\
\hline No conversion & $\mathrm{n}(\%)$ \\
\hline Laparoscopy & $271(98.9)$ \\
\hline Laparotomy & $1(0.4)$ \\
\hline None & $0.7)$ \\
\hline
\end{tabular}

Abbreviation: IQR, interquartile range.
Table 4 Comparison of complication, conversion and transfusion rates between surgeries performed with and without proctor $(n=274)$

\begin{tabular}{|c|c|c|}
\hline Variables & Without proctor & With proctor \\
\hline \multicolumn{3}{|c|}{ Need for transfusion n (\%) } \\
\hline No & $177(94.7)$ & $81(93.1)$ \\
\hline Yes & $10(5.3)$ & $6(6.9)$ \\
\hline \multicolumn{3}{|c|}{$p_{1}=0.611$} \\
\hline \multicolumn{3}{|c|}{ Complications n (\%) } \\
\hline No & $186(99.5)$ & $86(98.9)$ \\
\hline Yes & $\begin{array}{l}1(0.5) \\
\text { colonic fistula requir- } \\
\text { ing colostomy }\end{array}$ & $\begin{array}{l}1(1.1) \\
\text { ureter injury requir- } \\
\text { ing reconstruction }\end{array}$ \\
\hline \multicolumn{3}{|l|}{$p_{2}=0.535$} \\
\hline \multicolumn{3}{|c|}{ Surgical conversion n (\%) (laparoscopy/laparotomy) } \\
\hline No & $185(98.9)$ & $86(98.9)$ \\
\hline Yes & $\begin{array}{l}2(1.1) \\
\text { laparoscopy }\end{array}$ & $\begin{array}{l}1(1.1) \\
\text { laparotomy }\end{array}$ \\
\hline \multicolumn{3}{|l|}{$p_{2}>0.999$} \\
\hline
\end{tabular}

$\mathrm{p}_{1}$, chi-squared test; $\mathrm{p}_{2}$, Fisher exact test.

evidenced by the extent to which it has been more present in several specialties every day. ${ }^{14}$ Although most gynecological procedures could be done by robotics, and this technology has been recently made available in more than 30 hospitals in Brazil, the number of procedures is still low even in those hospitals, demonstrating the difficulty in qualifying a good number of surgeons to use this technology safely and effectively.

In this study, we focused on safety-related outcomes, evaluating two distinct groups of surgeons: 20 with little experience in robotics (mean: 4.35 cases per surgeon; range: 1-14) and 3 experienced robotic surgeons (mean: 62.33 cases per surgeon; range: $27-126$ ). The results demonstrated low rates of complications, transfusion and conversion, even when surgeons less experienced in robotics did the procedures, always assisted by an experienced proctor. However, we emphasize that our results have limitations related to study design, because it is retrospective and observational, with convenience sample, since we could not perform sample size analysis and may not have adequately identified confounding factors.

In a 2009 retrospective study that compared robotic surgery to laparoscopy for hysterectomy, the operative time was found to be like those reported in our casuistic. There were no statistically significant differences in operative time, blood loss or length of stay, and conversion to laparoscopy was not required. ${ }^{15}$ Reynolds and Advincula ${ }^{16}$ and Hanssens et $\mathrm{al}^{17}$ have shown that the time required for robotic surgery exceeds that for laparoscopy, though these results vary according to the surgeons' experience.

Fastrez et al, ${ }^{18}$ in a multicenter study with a group of 37 robot-assisted pelvic lymphadenectomies, reported that one patient had an aortic injury requiring conversion to laparotomy 
and one patient had a ureteral lesion treated without conversion. In the nine lymphadenectomies performed at HIAE, none of these complications were observed, a result which reflects the safety of this kind of approach for this procedure.

At the hospital evaluated herein, 66 myomectomies were performed through minimally invasive robot-assisted approach between 2008 and 2014 and no conversions were required. This result is compatible with the data from Cheng et al, ${ }^{19}$ in which 21 robotic myomectomies were performed between 2010 and 2012 with no conversions were required either.

In 2015, Corrado et $\mathrm{al}^{20}$ compared different surgical approaches for the treatment of endometrial cancer and showed that the group who underwent robotic surgery had a $1.4 \%$ rate of conversion to laparotomy and a $2.7 \%$ rate of conversion to laparoscopy, comparable to the rate observed at HIAE for all robotic gynecological surgeries between 2008 and 2014 (1.1\%). The same authors reported a $1.4 \%$ blood transfusion rate, slightly lower than the $5.8 \%$ observed in the current study. ${ }^{20}$

Although we had only one case of sacrocolpopexy, a systematic review conducted in 2016 by Pan et al, ${ }^{21}$ showed that the robotic approach is as safe as laparoscopy for performing the procedure, as there are no statistical differences between the two approaches in either complication rates or operative time. One of the biggest challenges of minimally invasive gynecological surgery is the difficulty in performing this type of approach on morbidly obese patients. $^{22}$ Being aware of this issue, minimally invasive surgeries must be introduced slowly and safely to those patients. Our casuistic had three patients with BMI $>40 \mathrm{~kg} / \mathrm{m}^{2}$, with no complications at all.

\section{Conclusion}

Robot-assisted laparoscopy in gynecological surgeries has been shown to be safe, with the presence of a proctor being critical for a successful transition for less experienced teams. This study demonstrates the safety of the model here presented for the introduction of robotic gynecological surgery into the hospital practice, but the rapid development in robot-assisted surgery calls for long-term prospective randomized controlled trials.

\section{Conflicts of Interest}

The authors have no conflicts of interest to disclose.

\section{Contributors}

Gomes M. T. V., Costa B. T., Parise Filho J. P., Vasconcelos A. L., Bottura B. F. and Marques R. M. contributed with project and interpretation of data, writing of the article, critical review of the intellectual content and final approval of the version to be published.

\section{Acknowledgments}

The authors would like to thank for Edna Roter, Fernanda Assir and Elivane da Silva Victor for their technical assistance.

\section{References}

1 García OF, Olvera HR, Montoya JJ. [Telemedicine and robotic surgery in gynecology]. Ginecol Obst Mex 2008;76:161-166

2 Rafiq A, Merrell RC. Telemedicine for access to quality care on medical practice and continuing medical education in a global arena. J Contin Educ Health Prof 2005;25(01):34-42. Doi: 10.1002/chp.7

3 Satava RM. Looking forward. Surg Endosc 2006;20(Suppl 2): S503-S504. Doi: 10.1007/s00464-006-0057-9

4 Senapati S, Advincula AP. Telemedicine and robotics: paving the way to the globalization of surgery. Int J Gynaecol Obstet 2005;91 (03):210-216. Doi: 10.1016/j.ijgo.2005.08.016

5 Fanfani F, Restaino S, Ercoli A, et al. Robotic versus laparoscopic surgery in gynecology: which should we use? Minerva Ginecol 2016;68(04):423-430

6 Cohn DE, Castellon-Larios K, Huffman L, et al. A prospective, comparative study for the evaluation of postoperative pain and quality of recovery in patients undergoing robotic versus open hysterectomy for staging of endometrial cancer. J Minim Invasive Gynecol 2016;23(03):429-434. Doi: 10.1016/j. jmig.2016.01.002

7 Berlinger NT. Robotic surgery-squeezing into tight places. N Engl J Med 2006;354(20):2099-2101

8 Dubin AK, Smith R, Julian D, Tanaka A, Mattingly P. A comparison of robotic simulation performance on basic virtual reality skills: simulator subjective versus objective assessment tools. J Minim Invasive Gynecol 2017;24(07):1184-1189. Doi: 10.1016/j. jmig.2017.07.019

9 Elliott DS, Frank I, Dimarco DS, Chow GK. Gynecologic use of robotically assisted laparoscopy: Sacrocolpopexy for the treatment of high-grade vaginal vault prolapse. Am J Surg 2004;188 (4A, Suppl)52S-56S. Doi: 10.1016/j.amjsurg.2004.08.022

10 Advincula AP, Song A, Burke W, Reynolds RK. Preliminary experience with robot-assisted laparoscopic myomectomy. J Am Assoc Gynecol Laparosc 2004;11(04):511-518. Doi: 10.1016/S10743804(05)60085-0

11 Bush SH, Apte SM. Robotic-assisted surgery in gynecological oncology. Cancer Contr 2015;22(03):307-313. Doi: 10.1177/ 107327481502200308

12 Manchana T, Puangsricharoen P, Sirisabya N, et al. Comparison of perioperative and oncologic outcomes with laparotomy, and laparoscopic or robotic surgery for women with endometrial cancer. Asian Pac J Cancer Prev 2015;16(13):5483-5488. Doi: 10.7314/APJCP.2015.16.13.5483

13 O'Malley DM, Smith B, Fowler JM. The role of robotic surgery in endometrial cancer. J Surg Oncol 2015;112(07):761-768. Doi: 10.1002/jso.23988

14 Li CY, Wang JW, Jia JT, Zhang NW. [Review of the developmental history of robotic surgery]. Zhonghua Yi Shi Za Zhi 2010;40(04): 229-233. Doi: 10.3760/cma.j.issn.0255-7053.2010.04.008

15 Nezhat C, Lavie O, Lemyre M, Gemer O, Bhagan L, Nezhat C. Laparoscopic hysterectomy with and without a robot: Stanford experience. JSLS 2009;13(02):125-128

16 Reynolds RK, Advincula AP. Robot-assisted laparoscopic hysterectomy: technique and initial experience. Am J Surg 2006;191 (04):555-560. Doi: 10.1016/j.amjsurg.2006.01.011

17 Hanssens S, Nisolle M, Leguevaque P, et al. Place de la robotique dans l'endométriose pelvienne profonde : à propos du registre de la SERGS. Gynecol Obstet Fertil 2014;42(11):744-748. Doi: 10.1016/j.gyobfe.2014.09.005

18 Fastrez M, Goffin F, Vergote I, et al. Multi-center experience of robot-assisted laparoscopic para-aortic lymphadenectomy for staging of locally advanced cervical carcinoma. Acta Obstet Gynecol Scand 2013;92(08):895-901. Doi: 10.1111/aogs.12150

19 Cheng HY, Chen YJ, Wang PH, et al. Robotic-assisted laparoscopic complex myomectomy: a single medical center's experience. Taiwan J Obstet Gynecol 2015;54(01):39-42. Doi: 10.1016/j. tjog.2014.11.004 
402 Safety Model for the Introduction Gomes et al.

20 Corrado G, Cutillo G, Pomati G, et al. Surgical and oncological outcome of robotic surgery compared to laparoscopic and abdominal surgery in the management of endometrial cancer. Eur J Surg Oncol 2015;41(08):1074-1081. Doi: 10.1016/j. ejso.2015.04.020

21 Pan K, Zhang Y, Wang Y, Wang Y, Xu H. A systematic review and meta-analysis of conventional laparoscopic sacrocolpopexy ver- sus robot-assisted laparoscopic sacrocolpopexy. Int J Gynaecol Obstet 2016;132(03):284-291. Doi: 10.1016/j.ijgo.2015.08.008

22 Kristensen SE, Mosgaard BJ, Rosendahl M, et al. Robot-assisted surgery in gynecological oncology: current status and controversies on patient benefits, cost and surgeon conditions - a systematic review. Acta Obstet Gynecol Scand 2017;96(03):274-285. Doi: 10.1111/aogs.13084 